
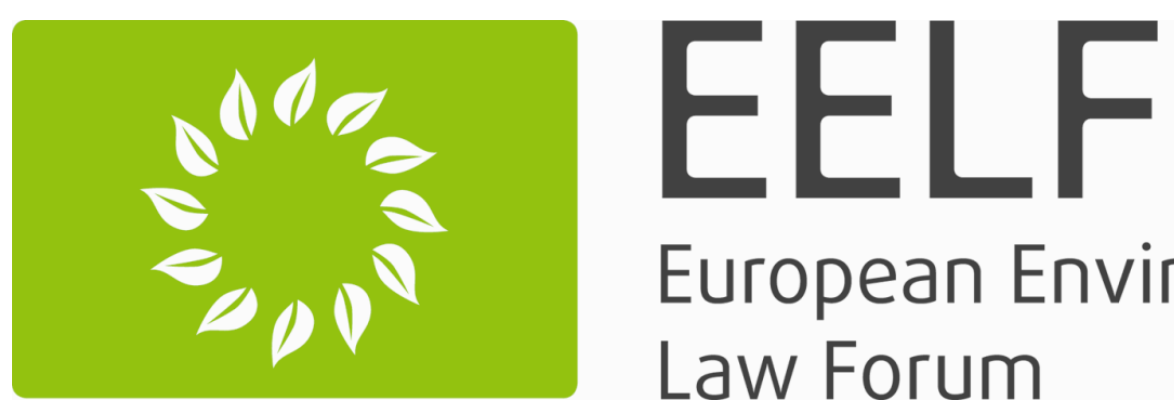

\title{
European Environmental Law Forum
}

\section{THIRD EELF CONFERENCE}

THE EFFECTIVENESS OF ENVIRONMENTAL LAW

\section{2-4 September 2015}

Faculty of Law and Political Science

Aix-en-Provence

\section{Programme}

Aix $*$ Marseille
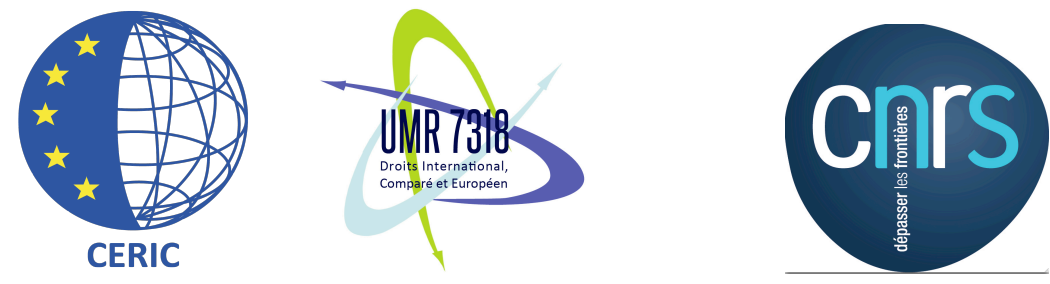
Wednesday 2 September
8.45-9.30:
Registration and coffee
First Plenary session: Chaired by Michel Prieur, Emeritus Professor, University of Limoges, (France)
Location: Dumas lecture hall

9.30-9.35: Welcome address by host institution

Philippe Bonfils, Dean of the Faculty of Law, Aix-Marseille University (France)

9.35-9.45: $\quad$ Welcome address by EELF

Moritz Reese, Chairman of the European Environmental Law Forum, Helmholtz Centre for Environmental Research, Leipzig (Germany)

9.45-10.15: Introduction to the Conference's topic

Sandrine Maljean-Dubois, Director of the CERIC, CNRS and Aix-Marseille University (France)

10.15-10.45: $\quad$ Fresh water, environmental protection and the quest for effectiveness

Laurence Boisson de Chazournes, University of Geneva (Switzerland)

10.45-11.15: $\quad$ Compliance and effectiveness

Liam Cashman, Deputy Head of Unit, Compliance promotion, governance and legal issues, European Commission (to be confirmed)

11.15-11.45:

The issue of effectiveness: Evaluating the current and emerging future European climate governance framework (from 2020 to 2030)

Sebastian Oberthür, Director of the Institute for European Studies, Vrije University, Brussels (Belgium)

11.45-12.15: $\quad$ General discussion

12.15-12.30: $\quad$ Practical information on parallel sessions and short presentation of the second EELF book

12.30-13.35: $\quad$ Lunch

13.35-15.40: $\quad$ Parallel session 1

\subsection{Flexible norms, role of standards and principles}

Chair: Vanessa Richard, CNRS and Aix-Marseille University (France)

Location: Dumas lecture hall

- The Effectiveness Dilemma of the Target \& Program Approach in EU Environmental Law, Moritz Reese, Helmholtz Centre for Environmental Research, Leipzig (Germany)

- Towards an effective programmatic approach: an initial set of recommendations to improve legal certainty, enforceability and adaptability in EU environmental law, Lorenzo Squintani Groningen University \& Marleen Van Rijswick, Utrecht University (Netherlands) 
- Changing Patterns of International Environmental Law-Making: Pragmatic Means of Addressing the Causes of Ineffective Implementation, Owen McIntyre, School of Law University College Cork National University of Ireland

- Framework for Assessing Law for Sustainability: Evaluating the Implementation and Impact of Legal Principles, Lydia Slobodian, Legal Officer Environmental Law Centre IUCN, Bonn (Germany)

\subsection{Legislative design facing environmental complexity}

Chair: Hans Woldendorp, Ministry for infrastructure and environment (Netherlands), University of Gent (Belgium), Institute for Infrastructure and Environment, Brussels (Belgium)

Location: Room Fabre 5

- Limits to the effectiveness of REACH using a life cycle approach, Thomas de Römph, University of Leuven, University Hasselt, and Policy Research Centre for Sustainable Materials Management (Belgium)

- Legal approaches to handle combination effects, Lena Gipperth, Department of Law, School of Business, Economics and Law University of Gothenburg (Sweden)

- Evaluating Waste Management: How Effective are Regulatory and Policy Frameworks in Supporting Industrial Symbiosis?, Katrien Steenmans, University of Surrey (United Kingdom)

- Ecological Connectivity Protection according to The European Union and Polish Law, Kamila Sobieraj, Piotr Zacharczuk, John Paul II Catholic University of Lublin (Poland)

\subsection{Participatory approaches}

Chair: Isabelle Michallet, University of Lyon 3 (France)

Location: Salle des Actes

- The role of public participation for the effectiveness of environmental law, Wolfgang Köck, Helmholtz Centre for Environmental Research, Leipzig (Germany)

- Citizens engagement in renewable energy: Negotiating energy transitions, Birgitte Egelund Olsen, Aarhus University School of Business and Social Sciences, Department of Law (Denmark)

- Effectiveness of participation of the local community and local authorities in the decision making in Renewable Energy, Tilak Ginige, Bournemouth University (United Kingdom)

- Public participation in environmental decision-making and Marine Spatial Planning and Coastal Management, Ines Roncha, University of Coimbra (Portugal) (to be confirmed)

\subsection{What combination of public and private norms for an effective policy mix?}

Chair: Mathilde Hautereau-Boutonnet, Aix Marseille University (France)

Location: Room 102

- The balance between public and private regulation within PES: a key to effectiveness? Adélie Pomade, University of Leuven (Belgium)

- EU Policy Mix for Forest Regulation: Interpreting Effectiveness, Yelena M. Gordeeva, Hasselt University (Belgium)

- Smart Mixes in relation to Transboundary Environmental Harm: Forest Governance as an Example, Jing Liu, Erasmus University Rotterdam (Netherlands)

- The regulation of "new" technologies in the European Union - is effectiveness at all possible? Leonie Reins, University of Leuven (Belgium)

15.40-16.05: $\quad$ Coffee break 


\subsection{Climate Change: on the way to COP 21 and the post 2020}

Chair: Matthieu Wemaëre, Paris and Brussels Bar Associations \& Aix-Marseille University (France) Location: Dumas lecture hall

- International Climate Change Law After the UNFCCC: Preparing for Failure, Navraj Singh Ghaleigh, University of Edinburgh (United Kingdom)

- International Climate Finance and Non-State Actors: the Transparency Imperative, Patricia Jonason, Södertörn University, Stockholm (Sweden), \& Richard Calland, University of Cape Tow (South Africa)

- Climate change action seeking for effectiveness: Cities networking and its legal implication, Julien Dellaux, Aix-Marseille University (France)

- Assessing Climate Preparedness: Indicators for Effective Adaptation to Climate Change in Dutch Vulnerable Sectors, Herman Kasper Gilissen, Utrecht Centre for Water, Oceans and Sustainability Law, Utrecht University (Netherlands)

\subsection{Nature Conservation Policies}

Chair: Eve Truilhé-Marengo, CNRS and Aix-Marseille University (France)

Location: Room 102

- Adopting an ecosystem approach based paradigm in environmental law, Elina Raitanen, University of Turku (Finland)

- The rise of the 'substitution principle' in EU environmental law: a key to enhancing sustainable development effectiveness and justiciability?, Charles-Hubert Born, University of Leuven (Belgium)

- The effectiveness of compensatory measures: the case for habitat banking, Valérie Dupont, University of Leuven (Belgium)

- Private property and markets in environmental goods: the case of the 'conservation covenant', Bonnie Holligan, University of Sussex (United Kingdom)

\subsection{Energy Law}

Chair: Wolfgang Köck, University of Leipzig (Germany)

Location: Salle des Actes

- The Barriers to the Implementation of the Directive 2010/31/EU on the Energy Performance of Buildings in the European Union and the Energy Community, Nicolas Pradel, Aix-Marseille University (France)

- Shift from Road to Rail According to the Swiss Constitution - About the (In-)Effectiveness of 'Overprotective' Norms, Markus Kern, University of Fribourg (Switzerland)

- On the effectiveness of Germany's Renewable Energy Sources Act, Sebastian Strunz, Erik Gawel, Helmholtz Centre for Environmental Research, Leipzig (Germany)

- Promoting electricity from renewable energy sources in France: is French law appropriate to reach the target?, Marie Lamoureux, Aix-Marseille University (France)

\subsection{Civil, administrative and criminal enforcement 1}

Chair: Bernard Vanheusden, Hasselt University (Belgium)

Location: Room Fabre 5

- Administrative and/or Criminal Enforcement, Jan Darpö, Uppsala University (Sweden)

- Civil, administrative and criminal sanctions in Cyprus, Natalia Charalampidou, Ruprecht-Karls University of Heidelberg \& Thessaloniki (Germany and Greece)

- Legislative Design for Effective Enforcement of Environmental Law - A UK Perspective, Eloise Scotford, King's College London, Jonathan Robinson, Environment Agency and University College London (United 
Kingdom)

- On the active toleration of environmental infringements and criminal liability of Administrations and Law Enforcement Agencies, Teresa Fajardo, University of Granada (Spain)

18.20-19.00: Refreshments

19.00-22.30: Conference dinner

Thursday 3 September

8.30-9.00: $\quad$ Coffee and croissants

9.00-11.05: Parallel session 3

\subsection{Mainstreaming and sustainable development in a multi level legal order}

Chair : Estelle Brosset, Aix-Marseille University (France)

Location : Salle des Actes

- The effectiveness of land-use planning options to integrate biodiversity and climate change aspects into land-use planning, Bernard Vanheusden, Hasselt University (Belgium)

- From conflicting to supporting EU policies - a long battle to secure cross-compliance with EU nature legislation, Sandra Jen, WWF European Policy Office, Brussels (Belgium)

- The European Court of Justice and the Effectiveness of International (Environmental) Treaty Provisions in the EU Legal Order, Benedikt Pirker, University of Fribourg (Switzerland)

- The Effectiveness of Environmental Constitutionalism: A Case Study, Erin Daly \& James R. May, Widener University, Delaware (United States)

\subsection{Incentives and marked-based instruments}

Chair: Helle Tegner Anker, University of Copenhagen (Denmark)

Location: Room Fabre 4

- Investors and Law Enforcers: How Multilateral Funds Incentivize Sustainable Forest Carbon Projects in Developing Countries, Yixin Xu, Erasmus University Rotterdam (Netherlands)

- Double burden in environmental regulation: the simultaneous application of a carbon tax and an emissions trading scheme to the offshore petroleum sector in Norway, Catherine Banet, Institute of Maritime Law, Petroleum and Energy Law Department, Oslo (Norway)

- The effectiveness of taxes on petroleum and its derivatives from concrete legislative experiences (Argentina, Brazil and USA), Rodolfo Salassa Boix, National University of Cordoba (Argentina)

- EU-ETS governance reform: What future for a European Carbon Market Agency?, Alice Monicat, Sciences Po, Paris (France)

\subsection{Human rights to improve the protection of the environment}

Chair: Hélène Tigroudja, Aix-Marseille University (France)

Location: Room Fabre 5

- Promoting Women's Participation: A Gender Approach for the Effectiveness of Environmental Law, Isabelle Michallet, Jean Moulin University, Lyon (France)

- The environmental protection of indigenous traditional knowledges and the active participation of indigenous peoples in planning, management and decision-making processes as means of improving the effectiveness of Environmental Law, Priscilla Cardoso Rodrigues, University of Roraima, Amazonia (Brazil), University of Coimbra (Portugal) 
- Environmental Human Rights and the Case for Achieving Effectiveness through Ecological Restoration?, Afshin Akhtarkhavari, University of Copenhagen (Denmark)

- Czech Public Defender of Rights and environmental impact assessment, Jitka Večeřová and Michaela Konečná, Masaryk University, Brno (Czech Republic)

\subsection{Dispute resolution: judicial and non-judicial mechanisms}

Chair: Luc Lavrysen, Ghent University (Belgium)

Location: Dumas Lecture Hall

- Monitoring the implementation of environmental law - Non-judicial and non-adversarial mechanisms (alternative dispute resolution), Alexandros Tsadiras, European University Cyprus (Cyprus)

- Green Judges - Role of Judiciary in Environmental Enforcement in China: Challenges and Prospects, Wen Xiang, University of Copenhagen (Denmark)

- Reassessing the Role of International Courts and Compliance Mechanisms in Ensuring Effectiveness of International Environmental Law, Antonio Cardesa-Salzmann, Rovira i Virgili University, Tarragona (Spain)

- Green judges: specialized environmental jurisdictions and the effectiveness of environmental law. The case of the National Green Tribunal of India in comparative perspective, Domenico Amirante, Napoli University (Italy) (to be confirmed)

\subsection{5-11.30: $\quad$ Coffee break}

\subsection{0-12.30: Parallel session 4}

\subsection{Simplification, better legislation, better regulation... decreasing environmental protection?}

Chair: Charles-Hubert Born, University of Leuven (Belgium)

Location: Dumas lecture hall

- Reducing administrative burdens, decreasing environmental protection? The regime of exemptions from permit requirements for waste disposal and recovery operations: challenges and prospects in Italy, Giada Dalla Gasperina, Trente (Italy)

- Better regulation of environment protection at EU level, really?, Matthieu Wemaëre, Paris and Brussels Bar Associations \& Aix-Marseille University (France)

\subsection{Global issues}

Chair: XX (to be confirmed)

Location: Salle des Actes

- Towards effective conservation mechanisms in areas beyond national jurisdiction, Beatriz de Sousa Fernandes, University of Edinburgh (United Kingdom) (to be confirmed)

- Assessment of the Effectiveness of Basel Convention on Transboundary Movement of Hazardous Waste, Wanying Huang, University of Strathclyde (United Kingdom)

\subsection{Does soft law matter?}

Chair: Rostane Mehdi, Aix-Marseille University (France)

Location: Room Fabre 4

- Soft law in environmental matters: the role of the ECJ, Mariolina Eliantonio, Maastricht University (Netherlands)

- The normative power, from hard to soft law: reflections from the climate change international regime, Marion Lemoine, Aix-Marseille University (France) 


\subsection{Access to justice (Member States)}

Chair: Tilak Ginige, Bournemouth University (United Kingdom)

Location: Room Fabre 5

- Procedural rights and effective justice - Danish wind energy experiences, Helle Tegner Anker, University of Copenhagen (Denmark)

- Study on the Possibilities for ENGOs to Claim Damages on Behalf of the Environment, Elena Fasoli, Queen Mary University of London, Member of the Aarhus Convention Compliance Committee (United Kingdom)

\subsection{0-13.45: Lunch}

\subsection{5-15.50: Parallel session 5}

\subsection{Access to justice (EU)}

Chair: Lorenzo Squintani, University of Groningen (Netherlands)

Location: Room Fabre 4

- Revisiting access to justice in environmental matters in the European Union: effectiveness or arrhythmia?, Vlachou Charikleia, University of Maine (USA), Athens Bar Association (Greece)

- Monitoring the Implementation of Environmental Law: The Importance and Challenges of Individual Standing in the EU Legal Context, Sanja Bogojević, Lund University (Sweden)

- Broader Standing for Private Parties to Increase the Effectiveness of EU Environmental Law, Lucas Bergkamp, Partner, Hunton \& Williams, Brussels (Belgium)

- Effectiveness of Environmental Law in the Case Law on Aarhus Convention, Petra Humlickova, Charles University (Czech Republic)

\subsection{Evolutive, adaptive, reflexive norms}

Chair: XX (to be confirmed)

Location: Dumas Lecture Hall

- Adaptive Law. An Approach to Design Effective Environmental Law, Jukka Similä, University of Lapland (Finland)

- Unmasking and tackling the challenges of ineffective environmental laws in the nuclear sector - a call for inclusive and reflexive regulation, Heldt Tobias, Maastricht University (Belgium)

- Evaluation of environmental legislation in the Netherlands, Hans Woldendorp, Ministry for infrastructure and environment (Netherlands), University of Gent (Belgium), Institute for Infrastructure and Environment Brussels (Belgium)

- Science and law in the environmental governance of the Mediterranean basin, Clio Bouillard and Guillaume Futhazar, Aix-Marseille University (France)

\subsection{Inspections}

Chair: Owen McIntyre, University College Cork National University of Ireland Location: Salle des Actes

- Making Chinese Environmental Protection Law Effective - Inspections, Yuhong Zhao, Chinese University of Hong Kong (Hong Kong)

- Environmental inspections and the EU: securing an effective role for a supranational Union legal framework, Martin Hedemann-Robinson, University of Kent's Law School, Canterbury (United Kingdom)

- Environmental Inspectors and prosecutors: is sharing information always useful?, Carole M. Billiet, University of Gent, and Sandra Rousseau, University of Leuven, (Belgium)

- Nuclear inspections, Emma Durand-Poudret and Claire Portier, Aix-Marseille University (France) 


\subsection{Civil, administrative and criminal enforcement 2}

Chair: Moritz Reese, Helmholtz Centre for Environmental Research, Leipzig (Germany)

Location: Room Fabre 5

- The effectiveness of the EU's legislative framework on environmental crime - insights from an ongoing research project, Christiane Gerstetter, Development Ecologic Institute (Germany)

- Towards Effective Implementation of the EU Environmental Crime Directive? The case of the waste trafficking and disposal offences, Ricardo Pereira, University of Westminster (United Kingdom)

- Assessing the Effectiveness of Sanctions in Environmental Law, Mark Poustie, University of Strathclyde Law School, Strathclyde Centre for Environmental Law \& Governance (United Kingdom)

- The ineffectiveness of civil responsibility for environmental damages caused by oil exploitation on the Brazilian continental shelf: the complementary use of the Conduct Adjustment Agreement, Carina Oliveira, University of Brasilia (Brazil)

\subsection{0-16.20 Side events}

- Legal approaches to effective protection of our soils - why we need an international soil regime Harald Ginsky, German Environmental Agency (Germany)

- Make it Work - Guidance on Drafting Provisions on Compliance Assurance in EU Environmental Law, Dutch Ministry of the Environment

16.20-16.45: Coffee break

Second Plenary session: Chaired by Agnès Michelot, University of La Rochelle, French Society for Environmental Law (France)

Room Dumas

16.45-16.50: Introduction

16.50-17.15: $\quad$ Overcoming the challenges in implementing EU environmental law: The role of IMPEL, John Seager, Chair, European Network for the Implementation and Enforcement of Environmental Law (Chair of the IMPEL Board)

17.15-17.40: $\quad$ Rethinking environmental sanctions: Towards an integrated system

Richard Macrory, University College London (United Kingdom)

17.40-17.55: $\quad$ Discussion

17.55-18.05: $\quad$ Conclusion

18.05-18.15: $\quad$ Announcement of the next EELF Conference

End of the day

18.15-19.15: $\quad$ EELF Managing Board and Advisory Board meeting

Chaired by Moritz Reese, Chairman of the European Environmental Law Forum, Helmholtz Centre for Environmental Research, Leipzig (Germany) 
Friday 4 September 2015

Social program: Naturalist walking and picnic in Montagne Sainte-Victoire (9h00-15h30)

To get more details and register, please click here. 